\title{
Evaluation of Cognitive Function Using Objective and Subjective Tests in the Obstructive Sleep Apnea Syndrome
}

\section{Obstrüktif Uyku Apne Sendromunda Kognitif Fonksiyonların Objektif ve Subjektif Testlerle Değerlendirilmesi}

\author{
Ayşın Kısabay Ak, Ümmü Serpil Sarı*, Bilge Oktan, Tuğba Korkmaz, Gönül Dinç Horasan**, Deniz Selçuki, Hikmet Yılmaz \\ Celal Bayar University Faculty of Medicine, Department of Neurology, Manisa, Turkey \\ *Balıkesir University Faculty of Medicine, Department of Neurology, Balıkesir, Turkey \\ **Izmir University of Economics Faculty of Medicine, Department of Public Health, Izmir, Turkey
}

\begin{abstract}
Objective: The primary and secondary consequences which related to obstructive respiration to occur during sleep cause cognitive, emotional and behavioral changes indirectly. Aim of the present study was to evaluate quality of sleep and relationship between quality of sleep and cognitive function at baseline and during treatment in the patients having diagnosis of severe Obstructive Sleep Apnea syndrome (OSAS) being followed in sleep laboratory.

Materials and Methods: Pittsburg, Epworth and Stroop tests to assess patient attention; P300 test was applied for the evaluation of memory and attention.

Results: When the pre-treatment and post-treatment cognitive functions of the patients were compared; there was a significant decrease in daytime sleepiness after treatment $(p=0.000)$ and a significant improvement in latency of P300 test $(p=0.000-p=0.001-p=0.004)$. In Pittsburgh study; the pre-treatment total sleep quality scores were consistent with poor sleep quality, while the mean value obtained after treatment was found to be related to the healthy sleepiness $(p=0.000)$. In the Stroop test for measuring attention, the rate of error correction obtained after treatment was significantly improved $(\mathrm{p}=0.010)$.

Conclusion: In patients diagnosed with severe OSAS; the negative effects of disease on attention, alertness, and memory, challenges on maintaining the attention and its negative effects on the structure of sleep has been shown by using Stroop, Pittsburgh, P300 and Epworth tests unlike other publications. As a result of the tests performed after the treatment, the fact that it is an important development in the disease shows us how the treatment is important and necessary. Keywords: Obstructive Sleep Apnea syndrome, P300, Stroop, Pittsburg, sleep
\end{abstract}

Öz

Amaç: Obstrüktif solunumla ilgili olarak uyku sırasında ortaya çıkan birincil ve ikincil sonuçlar, indirekt olarak bilişsel, duygusal ve davranışsal değişikliklere neden olmaktadır. Bu çalışmada; uyku laboratuvarında ağır Obstrüktif Uyku Apnesi sendromu (OUAS) teşhisi konulan hastaların başlangıç ve tedavi aşamasındaki uyku kalitesinin ve uyku kalitesi ile bilişsel fonksiyonlar arasındaki ilişkinin değerlendirilmesi amaçlanmaktadır.

Gereç ve Yöntem: Hastaların dikkatlerinin değerlendirilmesi için Pittsburg, Epworth ve Stroop testi; hafıza ve dikkatlerinin değerlendirilmesi için P300 testi uygulanmıştır.

Bulgular: Hastaların tedavi öncesi ve tedavi sonrası bilişsel işlevleri karşılaştırıldığında; tedavi sonrası gündüz uyuklamasında önemli bir azalma olduğu $(p=0,000)$ ve $P 300$ testi latansında belirgin düzelme olduğu $\quad(p=0,000-p=0,001-p=0,004) \quad$ görülmüştür. Pittsburgh çalışmasında; tedavi öncesi toplam uyku kalitesi skorları, uyku kalitesinin kötü olmasıyla uyumlu iken, tedavi sonrası elde edilen ortalama değer ise uykunun sağlıklı olmasıyla ilişkili bulunmuştur $(p=0,000)$. Dikkati ölçmek için yapılan Stroop testinde tedavi sonrasında elde edilen hata düzeltme oranının önemli biçimde düzeldiği görülmüştür $(p=0,010)$.

Sonuç: Ağır OUAS tanısı konulan hastalarda; hastalığın dikkat, uyanıklık ve hafıza üzerindeki olumsuz etkileri, dikkati sürdürme konusunda yaşanan zorluklar ve bunların uyku yapısı üzerindeki olumsuz etkileri, diğer yayınlardan farklı olarak; Stroop, Pittsburgh, P300 ve Epworth testleriyle ortaya konulmuştur. Tedavi sonrasında yapılan testlerin sonucunda, hastalıkta önemli bir gelişme olduğunun ortaya konulması, tedavinin ne denli önemli ve gerekli olduğunu bize göstermektedir. Anahtar Kelimeler: Obstruktif Uyku Apne sendromu, P300, Stroop, Pittsburg, uyku 


\section{Introduction}

Obstructive Sleep Apnea syndrome (OSAS) is defined as a condition characterized by lowered oxygen saturation in the blood and interruption of the sleep due to repeating upper respiratory tract obstruction during sleep. OSAS is observed in $2 \%$ of the old women and $4 \%$ of the old men while this figure rises up to $42 \%$ after age of 65 (1-4).

Primary mechanisms important in pathophysiology of OSAS include recurrent attacks of hypoxemia, hypercapnia, and arousals. Primary as well as secondary consequences of obstructive respiration during sleep theoretically causes alterations in cognition, emotion, and behavior, learning, memory, and executive control (1-3). Arousals caused by respiratory events lead to over sleepiness and reduced vigilance during daytime. The most prominent negative alteration is on attention, wakefulness, and executive function $(2,3,5-8)$.

In the present study, efficacy of continuous positive airway pressure (CPAP) treatment was evaluated using objective parameters by measuring cognitive function and sleep quality initially and at the third month of specific treatment in the patients with severe OSAS [apnea-hipopnea index (AHI) 230] followed by sleep unit of sleep laboratory of neurology department. It was planned to evaluate the relationship of sleep quality and cognitive function at the $3^{\text {rd }}$ month of the CPAP treatment.

\section{Materials and Methods}

Main objective of the present study was to evaluate the relationship of sleep quality and cognitive function during (at the $3^{\text {rd }}$ month) the CPAP treatment. It was planned to compare the pre-treatment and post-treatment neuropsychiatric tests (Stroop, Pittsburgh, and Epworth) and P300 data by recording P300 potentials in addition to the cognitive tests in order to evaluate different cognitive functions such as attention and memory in the patients with OSAS. Another aim of the current study was to create a widespread reflex to use the Stroop test in sleep disorders and in the patients with dementia in which cognition is altered in addition to the patients with OSAS.

Following approval from the Celal Bayar University Faculty of Medicine Local Ethics Committee (date/approval no: 16.04.2014/20478486), the present study included the first 30 patients with $\mathrm{AHI}>30$ (severe OSAS) presenting to the neurology-sleep polyclinic. All the patients have signed the approval form the patients underwent Pittsburgh and Epworth tests to evaluate sleep quality, Stroop test to evaluate attention, and P300 evaluate working memory and attention.

\section{Inclusion of the Subjects}

The patients slept overnight in the sleep laboratory and underwent polysomnographic examination using 26 channels sleep-screen 26 polysomnography (PSG) (Somnologica Studio User Manual Medical). Following PSG exam, the subjects with severe OSAS were defined. They were started routine treatment for risk factors and CPAP treatment. Mean duration for using the device was 6.2 hours.

AHI below 5 in PSG investigation of all subjects in the normal control group for P300 and Stroop test OSAS investigation revealed that no subjects had any complaint.
Inclusion criteria: Diagnosis based on PSG (AHI >30). Being graduated from graduated school at least, having signed the written informed consent, absence of exclusion criteria, age $>18$ years.

Exclusion criteria: Presence of any known pulmonary disease, congestive heart failure. History of recent or prior head injury, any neurological condition, meningitis or encephalitis, clinical or laboratory evidence of hypothyroidism, patients using medications for any psychiatric condition to impair cognitive function such as bipolar disorder or schizophrenia, substance abuse or addiction, the patients with OSAS related to rapid eye movement or position, with auditory disability were excluded.

\section{Tests Applied to the Patients}

\section{a) Epworth Sleepiness Scale}

Some questionnaires that are compatible to varying degree with some objective methods to measure sleepiness used in order to detect over sleepiness. Of these, the most widely used one is Epworth Sleepiness Scale. The lowest score of this scale is 0 and the highest one is 24 with higher points indicating increasing degree of sleepiness.

\section{b) Stroop Test}

It measures the ability to change perceptual function and reaction, maintaining aim-directed behavior, information processing speed, concentration, and attention. It is a test measuring the attention based on ability to read color words and the colors. Number of the errors, corrected reactions, duration of evaluation for each card, and total duration are evaluated (Table 1).

\section{c) Pittsburgh Sleep Quality Scale}

Each subject was scored based on assessment form of Pittsburgh Sleep Quality Scale (PSQS).

Parameters below: Subjective sleep quality, time to sleep, duration of sleep, efficacy of sleep, conditions affecting the sleep, use of hypnotic medications, daytime sleepiness.

For each domain of the scale, a separate score ranging between 0 and 3 was calculated with higher scores indicating impaired quality of sleep.

Zero to five points: Healthy sleep, 6 to 10 points: poor sleep, more than 10 points: consistent with long-term sleep disorder.

\section{d) P300}

Event-related evoked potentials allowing measurement of cognitive function in the brain such as P300 is known as specific index of cognition. P300 involves distinguishing the randomly coming infrequent stimuli from others. The subjects were asked to count the low-pitched voices from among the high-pithed voices. P300 reflects cognitive decision-making, distinguishing the stimuli, and classifying the content and comparing with the marks in the memory. Thus P300 indicated to reflect updating memory and attentional resource allocation P300 potential in indicating silence and subclinic lesions. They can demonstrate electrical abnormalities in neural tissues. In the current study group, the event-related evoked potentials (P300) were obtained using standard "old ball" paradigm (array of alternant stimuli). Event-related evoked potentials of the OSAS and control groups were recorded in a silent room in the electromyography (EMG) laboratory of our clinic using 
Keypoint Dantec Denmark 8-channel EMG/Evoked Potential instrument with the patient in sitting position. All electrode impedances were less than $5^{\prime} \Omega$. Using $\mathrm{Ag} / \mathrm{AgCl}$ disk electrodes, the active electrodes were placed on $\mathrm{Fz}, \mathrm{Cz}$, and $\mathrm{Pz}$ and the reference electrode of $\mathrm{Fz}$ on the right earlobe and the reference $\mathrm{Cz}$ and $\mathrm{Pz}$ electrodes on the left earlobe based on international 10-20 system. Recording was made from Fz, Cz, and Pz points in all subjects. Latency and amplitude of the resultant P300 waves were recorded.

\section{Statistical Analysis}

Data obtained in the present study were entered to the database created with SPSS (Statistical Package for Social Sciences) software and statistical analyzed were done using the same software. Normal distribution of the continuous variables and the sub-sections was examined. Considering the graphic examination as well as normality tests and size of the sample, it was concluded that the all variables didn't show normal distribution. Mean, standard deviation, median, minimum and maximum of these variables were presented. Non-parametric methods were preferred in exploring the difference of distribution between the groups. Mann-Whitney's test was used to compare the independent groups. Wilcoxon's signed-ranks test was used to compare the dependent groups. For all statistical comparisons, error level of type I was set as alpha: 0.05 and tested as two-tailed. In the case of " $p$ " value being $<0.05$, the difference between the groups was considered as statistically significant.

\section{Results}

The present study included 30 patients in whom 23 were male and 7 were female. Range of age was 33 to 73 years with mean age being 49.63 years. No statistically significant difference was found between the groups of patients and controls age $(p=0.853)$.

Mean AHI score was 35.00 \pm 3.60 (range: 31.00-46.00) and mean oxygen saturation was 76.50 6.39 (55.00-84.00).

Difference was found to be statistically significant when the preand post-treatment Epworth tests values were compared with each other $(p=0.000)$ (Table 2$)$.

No statistically significant difference was found when the preand post-treatment values in the domain 1, 2, 3, and 4 were compared ( $p=0.422,0.147,0.453,0.113$, respectively). In the domain 5 which was more complicated, statistically significant difference was found between the pre- and post-treatment values $(p=0.020)$ (Table 3$)$.

In regard to total mistakes, mean number of total mistakes pre-post treatment, the difference was statistically insignificant $(p=0.125)$. In regard to total corrections, mean number of corrections pre-post treatment, the difference was found to be significant $(p=0.010)$ (Table 4,5$)$.

\begin{tabular}{|l|l|l|l|}
\hline Table 1. Stroop test & Stimulators & Content of the stimulating card & Task \\
\hline Steps & Card \#1 & Names of colors printed in black & Reading the names of colors \\
\hline Step 1 & Card \#2 & Names of colors printed in different colors & Reading the names of colors \\
\hline Step 2 & Card \#3 & Circles printed in color & Telling name of the color \\
\hline Step 3 & Card \#4 & Word printed in color & Telling name of the color \\
\hline Step 4 & Card \#5 & Names of colors printed in different colors & Telling name of the color \\
\hline Step 5 &
\end{tabular}

Table 2. Between values of Epworth test pre-treatment and post-treatment

\begin{tabular}{|l|l|l|l|l|l|l|l|}
\hline & Valid $\mathbf{n}$ & Mean & $\begin{array}{l}\text { Standard } \\
\text { deviation }\end{array}$ & Median & Minimum & Maximum & Range \\
\hline Epworth (pre-treatment) & 30 & 11.03 & 6.21 & 11.00 & 2.00 & 21.00 \\
\hline Epworth (post-treatment) & 30 & 3.97 & 3.53 & 3.00 & 0.00 & 19.00 \\
\hline
\end{tabular}

Table 3. Between steps of Stroop test pre-treatment and post-treatment

\begin{tabular}{|l|l|l|l|l|l|l|l|}
\hline & Valid $\mathbf{n}$ & Mean & Standard deviation & Median & Minimum & Maximum & Range \\
\hline Domain 1 time (pre-treatment) & 30 & 11.00 & 2.33 & 10.48 & 7.94 & 18.41 & 10.47 \\
\hline Domain 1 time (post-treatment) & 30 & 11.39 & 2.88 & 10.88 & 7.00 & 18.59 & 11.59 \\
\hline Domain 2 time (pre-treatment) & 30 & 11.71 & 3.19 & 10.72 & 7.89 & 21.31 & 13.42 \\
\hline Domain 2 time (post-treatment) & 30 & 12.80 & 3.70 & 11.49 & 7.89 & 20.76 & 12.87 \\
\hline Domain 3 time (pre-treatment) & 30 & 12.03 & 3.61 & 10.89 & 7.34 & 20.49 & 13.15 \\
\hline Domain 3 time (post-treatment) & 30 & 13.20 & 5.79 & 10.95 & 6.67 & 28.19 & 21.52 \\
\hline Domain 4 time (pre-treatment) & 30 & 20.93 & 8.03 & 19.16 & 9.95 & 40.52 & 30.57 \\
\hline Domain 4 time (post-treatment) & 30 & 20.22 & 7.48 & 18.28 & 10.53 & 39.00 & 28.47 \\
\hline Domain 5 time (pre-treatment) & 30 & 31.08 & 13.20 & 25.17 & 16.45 & 60.86 & 44.41 \\
\hline Domain 5 time (post-treatment) & 30 & 27.76 & 10.08 & 24.59 & 15.00 & 48.59 & 33.59 \\
\hline
\end{tabular}


In regard to overall scoring of PSQS, the difference was found to be statistically highly significant $(p=0.000)$. That is to say that mean value was consistent with poor sleep before the treatment while it was consistent with healthy sleep.

The scale consists of 7 parameters; each parameter is scored with one of the 0-1-2-3 points. Zero indicates the best situation while 3 (three) indicates the worst one. Since range of the numerical values in the sub-sections of Pittsburg test is narrow, no separate statistical evaluation was made (Table 6).

When latency $(\mathrm{Fz}, \mathrm{Cz}, \mathrm{Pz})$ and amplitude of the P300 (Cz) wave were compared between the pre-treatment and post-treatment periods, difference was found to be statistically significant $(p=0.000-0.001-0.004-0.000$ respectively). Statistically significant difference was found when pre-treatment P300 latency and amplitude values were compared to normal control latency and amplitude values ( $\mathrm{p}=0.041-0.048-0.058-0.000$ respectively) while no significant difference was found when post-treatment values were compared to those in the normal control group $(p=0.314-0.544-0.450-0.198$ respectively) (Table 7).

\section{Correlation Tests}

There were correlations between mean oxygen saturation and P300 $\left(r=-0.914^{* *}\right)$, between mean AHI and oxygen saturation $\left(r=-0.945^{\star *}\right)$ as well as latency of P300 $\left(r=0.909^{\star *}\right)$.

\section{Discussion}

Primary events in the OSA include recurrent attacks of hypoxemia, hypercapnia, and arousals. Both primary and secondary consequences of the obstructive respiration during sleep lead to emotional and behavioral alterations (1). Hypoxemia in the patients with OSAS may have different effects on the cognitive function and may lead to permanent anoxic damage to the central nervous system, neuronal lesions and atrophy in the hippocampus (9-17). For the patients with OSAS, it has been suggested that hypoxemia has negative regulating effect on the memory function and there is a significant reduction especially in short-term memory (1-3).

The study has been shown that cognitive tests are negatively affected in the patients with OSAS associated with hypoxemia compared to those with OSAS unassociated with hypoxemia (18). In another study, instant memory has been shown to be better in higher degree of hypoxemia in the blood than in higher degree of hypoxemia. In the clinical and animal experiments, intermittent hypoxemia has been shown to have protective effects against cardiovascular system, brain, and memory function (19). Severe OSAS also leads to impaired learning ability, inhibition of involuntary actions and thoughts, and cognitive dysfunction in such abilities as prospective planning and thinking about the future (1-8,20-23).

Frequent apneas lead to frequent arousals and interrupted sleep, causing daytime sleepiness. A significant correlation has been found between daytime sleepiness and cognitive function $(24,25)$. OSAS causes daytime sleepiness, leading to poor quality of life and cognitive alterations $(17,26,27)$.

It is remarkable that there have been several studies on subtypes of memory for memory dysfunction associated with OSAS. Short-term visual memory is more sensitive to the disease and is altered more. In addition to short-time memory, long-term memory may also be altered $(6,28,29)$. It has been shown that there is serious impairment in verbal memory tests compared to the normal control group and the visual memory tests are not altered $(30,31)$.

On the other hand, there have been studies not only on memory and attention but also on understanding and intelligence in OSAS. It has been observed that executive and psychomotor function is impaired while overall intelligence and understanding function is spared in the adults $(28,32,33)$. Similarly, in a meta-analysis involving 25 studies it was seen that there was no difference in intelligence between the patients with OSAS and normal control group (9).

Another method used widely to evaluate cognitive and attention deficits is event-related potentials (ERPs) (34) P300 wave reflects evaluation of the initial stimulus, frontal lobe activation during the transfer process through corpus callosum, and subsequent parietal and hippocampal processes. In these patients, one or both of hypoxia and sleep deprivation seem to alter memory process, leading to increase in delay and decrease amplitude of P300 wave in the ERP recordings. Accordingly, it causes reduced vigilance and increased time to react (35-37).

It was observed that latency decreased and amplitude increased. Time to react, which was long before the treatment, decreased after the treatment. Statistically significant difference was found when pre-treatment P300 latency and amplitude values were

\begin{tabular}{|l|l|l|l|l|l|l|l|}
\hline Table 4. Rates of mistakes and corrections for mistakes in the Stroop test pre-treatment and post-treatment \\
\hline & Valid $\mathbf{n}$ & Mean & $\begin{array}{l}\text { Standard } \\
\text { deviation }\end{array}$ & Median & Minimum & Maximum & Range \\
\hline Total mistake (pre-treatment) & 30 & 2.57 & 2.90 & 1.00 & 0.00 & 11.00 & 11.00 \\
\hline Total mistake (post-treatment) & 30 & 1.97 & 2.87 & 1.00 & 0.00 & 10.00 & 10.00 \\
\hline Total correction (pre-treatment) & 30 & 1.50 & 2.08 & 1.00 & 0.00 & 9.00 & 9.00 \\
\hline Total correction (post-treatment) & 30 & 2.10 & 1.92 & 1.50 & 0.00 & 8.00 \\
\hline
\end{tabular}

Table 5. Comparison between the total scores of Pittsburgh sleep evaluation scale pre-treatment and post-treatment

\begin{tabular}{|l|l|l|l|l|l|l|l|}
\hline & Valid $\mathbf{n}$ & Mean & Standard deviation & Median & Minimum & Maximum & Range \\
\hline Total score (pre-treatment) & 30 & 8.80 & 3.61 & 8.50 & 3.00 & 18.00 \\
\hline Total score (post-treatment) & 30 & 4.07 & 2.59 & 4.00 & 1.00 & 15.00 \\
\hline
\end{tabular}




\begin{tabular}{|c|c|c|c|c|c|}
\hline \multicolumn{6}{|c|}{ Quality of sleep (pre-treatment) } \\
\hline & & Frequency & Percent & Valid percent & Cumulative percent \\
\hline \multirow[t]{4}{*}{ Valid } & 0.00 & 2 & 6.7 & 6.7 & 6.7 \\
\hline & 1.00 & 7 & 23.3 & 23.3 & 30.0 \\
\hline & 2.00 & 14 & 46.7 & 46.7 & 76.7 \\
\hline & 3.00 & 7 & 23.3 & 23.3 & 100.0 \\
\hline \multicolumn{6}{|c|}{ Quality of sleep (post-treatment) } \\
\hline \multirow[t]{3}{*}{ Valid } & 0.00 & 6 & 20.0 & 20.0 & 20.0 \\
\hline & 1.00 & 23 & 76.7 & 76.7 & 96.7 \\
\hline & 2.00 & 1 & 3.3 & 3.3 & 100.0 \\
\hline \multicolumn{6}{|c|}{ Latency (pre-treatment) } \\
\hline \multirow[t]{3}{*}{ Valid } & 0.00 & 11 & 36.7 & 36.7 & 36.7 \\
\hline & 1.00 & 11 & 36.7 & 36.7 & 73.3 \\
\hline & 2.00 & 8 & 26.7 & 26.7 & 100.0 \\
\hline \multicolumn{6}{|c|}{ Latency (post-treatment) } \\
\hline \multirow[t]{2}{*}{ Valid } & 0.00 & 15 & 50.0 & 50.0 & 50.0 \\
\hline & 1.00 & 15 & 50.0 & 50.0 & 100.0 \\
\hline \multicolumn{6}{|c|}{ Duration of sleep (pre-treatment) } \\
\hline \multirow[t]{4}{*}{ Valid } & 0.00 & 7 & 23.3 & 23.3 & 23.3 \\
\hline & 1.00 & 11 & 36.7 & 36.7 & 60.0 \\
\hline & 2.00 & 5 & 16.7 & 16.7 & 76.7 \\
\hline & 3.00 & 7 & 23.3 & 23.3 & 100.0 \\
\hline \multicolumn{6}{|c|}{ Duration of sleep (post-treatment) } \\
\hline \multirow[t]{3}{*}{ Valid } & 0.00 & 14 & 46.7 & 46.7 & 46.7 \\
\hline & 1.00 & 13 & 43.3 & 43.3 & 90.0 \\
\hline & 2.00 & 3 & 10.0 & 10.0 & 100.0 \\
\hline \multicolumn{6}{|c|}{ Efficacy of sleep (pre-treatment) } \\
\hline & & Frequency & Percent & Valid percent & Cumulative percent \\
\hline \multirow[t]{3}{*}{ Valid } & 1.00 & 16 & 53.3 & 53.3 & 53.3 \\
\hline & 2.00 & 11 & 36.7 & 36.7 & 90.0 \\
\hline & 3.00 & 3 & 10.0 & 10.0 & 100.0 \\
\hline \multicolumn{6}{|c|}{ Efficacy of sleep (post-treatment) } \\
\hline \multirow[t]{3}{*}{ Valid } & 0.00 & 20 & 66.7 & 66.7 & 66.7 \\
\hline & 1.00 & 9 & 30.0 & 30.0 & 96.7 \\
\hline & 2.00 & 1 & 3.3 & 3.3 & 100.0 \\
\hline \multicolumn{6}{|c|}{ Negative factors (pre-treatment) } \\
\hline \multirow[t]{4}{*}{ Valid } & 0.00 & 1 & 3.3 & 3.3 & 3.3 \\
\hline & 1.00 & 13 & 43.3 & 43.3 & 46.7 \\
\hline & 2.00 & 14 & 46.7 & 46.7 & 93.3 \\
\hline & 3.00 & 2 & 6.7 & 6.7 & 100.0 \\
\hline \multicolumn{6}{|c|}{ Negative factors (post-treatment) } \\
\hline \multirow[t]{3}{*}{ Valid } & 0.00 & 9 & 30.0 & 30.0 & 30.0 \\
\hline & 1.00 & 11 & 36.7 & 36.7 & 66.7 \\
\hline & 2.00 & 10 & 33.3 & 33.3 & 100.0 \\
\hline
\end{tabular}




\begin{tabular}{|c|c|c|c|c|c|}
\hline Table & & & & & \\
\hline Hypn & & & & & \\
\hline Valid & 0.00 & 28 & 93.3 & \begin{tabular}{|l|}
93.3 \\
\end{tabular} & 93.3 \\
\hline & 2.00 & 2 & 6.7 & 6.7 & 100.0 \\
\hline Hypn & & & & & \\
\hline Valid & 0.00 & 26 & 86.7 & 86.7 & 86.7 \\
\hline & 1.00 & 4 & 13.3 & 13.3 & 100.0 \\
\hline Daytir & & & & & \\
\hline Valid & 0.00 & 6 & 20.0 & 20.0 & 20.0 \\
\hline & 1.00 & 11 & 36.7 & 36.7 & 56.7 \\
\hline & 2.00 & 9 & 30.0 & 30.0 & 86.7 \\
\hline & 3.00 & 4 & 13.3 & \begin{tabular}{|l|}
13.3 \\
\end{tabular} & 100.0 \\
\hline Daytir & & & & & \\
\hline Valid & 0.00 & 15 & 50.0 & 50.0 & 50.0 \\
\hline & 1.00 & 13 & 43.3 & \begin{tabular}{|l}
43.3 \\
\end{tabular} & 93.3 \\
\hline & 2.00 & 2 & 6.7 & \begin{tabular}{|l|l}
6.7 \\
\end{tabular} & 100.0 \\
\hline
\end{tabular}

\begin{tabular}{|c|c|c|c|c|c|c|c|}
\hline & Valid $n$ & Mean & $\begin{array}{l}\text { Standard } \\
\text { deviation }\end{array}$ & Median & Minimum & Maximum & Range \\
\hline P300 FZ (pre-treatment)-latency & 30 & 342 & 26 & 340 & 302 & 430 & 128 \\
\hline P300 FZ (post-treatment)-latency & 30 & 337 & 25 & 334 & 300 & 421 & 121 \\
\hline P300 CZ (pre-treatment)-latency & 30 & 342 & 27 & 338 & 298 & 433 & 135 \\
\hline P300 CZ (post-treatment)-latency & 30 & 335 & 22 & 331 & 302 & 412 & 110 \\
\hline P300 PZ (pre-treatment)-latency & 30 & 344 & 27 & 341 & 300 & 435 & 135 \\
\hline P300 PZ (post-treatment)-latency & 30 & 336 & 19 & 330 & 310 & 400 & 90 \\
\hline P300 FZ (Normal)-latency & 30 & 329 & 15 & 330 & 300 & 352 & 52 \\
\hline P300 CZ (Normal)-latency & 30 & 330 & 16 & 328 & 305 & 364 & 59 \\
\hline P300 PZ (Normal)-latency & 30 & 332 & 17 & 328 & 305 & 363 & 58 \\
\hline Amplitüde CZ (pre-treatment) & 30 & 5.33 & 1.47 & 5.00 & 3.00 & 8.00 & 5.00 \\
\hline Amplitüde CZ (post-treatment) & 30 & 6.96 & 1.67 & 7.45 & 4.00 & 10.00 & 6.00 \\
\hline Amplitüde CZ (Normal) & 30 & 7.57 & 1.52 & 8.00 & 5.00 & 11.00 & 6.00 \\
\hline
\end{tabular}

compared to normal control latency and amplitude values $(p<0.05)$ while no significant difference was found when posttreatment values were compared to those in the normal control group ( $p>0.05)$.

Although P300 latencies were significantly decreased following treatment in a study, difference was not found to be significant when it was compared to the control group (38). In another study, recovery in the latency before age of 45 was found to be statistically significant it was insignificant in elderly patients (39). As our study, the fact that P300 latency was significantly less relative to the control group indicates that it was resistant to the treatment.

Stroop test used in studies on dementia and attention was used for OSAS in contrast to previous studies. In the test consisting of 5 steps, no statistically significant difference was found between the pre- and post-treatment reading times in the Domain 1, 2, 3 and 4 . The processes conducted by the patients in the first
4 defined domains were considered as easier by the patients. Domain 5, involving a more complicated process, showed a statistically significant difference between pre- and posttreatment values $(p<0.05)$. Pre-treatment and post-treatment values of Stroop tests were not found to be significantly different although rate of making mistake decreased $(p>0.05)$. Another fact to be considered was that effort to correct the mistake increased significantly following the treatment, indicating that awareness improved significantly in addition to attention function $(p<0.05)$.

These two tests have been seen to be used especially in the studies investigating the structure of sleep. One of the unique differences of the present study on OSAS was that it used these tests. These parameters are subjective. Tests are needed that may be chosen and may serve as a filter in the patients with OSAS. Furthermore, it was concluded that the Stroop and P300 tests would contribute to subjective-objective parameters 
because they were easy, fast, and non-invasive tests.

We used Epworth Sleepiness scale to evaluate daytime sleepiness and PSQS to evaluate quality of the sleep.

Pittsburgh Sleep Evaluation scale was examined in detailed way. It was observed that latency of sleep increased, efficacy of sleep was low, and quality of sleep was impaired in the patients with severe OSAS. It was also seen that the patients needing medications to sleep showed more tendency to sleep during daytime. It was seen that quality of sleep improved, latency of sleep increased, duration and efficacy of sleep increased, daytime sleepiness and amount of medications taken in night to sleep reduced after the treatment.

In the Pittsburgh Sleep Evaluation scale, mean score was consistent with poor quality of sleep before the treatment whereas it was consistent with healthy sleep $(p<0.05)$.

Furthermore, in the present study difference was found to be statistically significant when the pre- and post-treatment Epworth tests values were compared $(p<0.05)$. It was observed that vigilance increased after CPAP treatment.

It was observed that there was positive correlation among the tests used in the present study. The most significant correlation was between P300 and Epworth sleepiness tests ( $r=0.065)$.

In the patients with severe disease, cognitive disorders and low performance are easier to observe. OSAS treatment with CPAP leads to significant improvement in cognitive function, performance, and attention although magnitude of this improvement varies $(9,10,21-23)$ while half of the studies showed improvement in executive function (17) and memory (40). Arousals disappear and interruption of sleep are prevented and daytime symptoms, especially tendency to sleep improves significantly after the treatment $(2,3)$.

A study by Ferini-Strambi et al. (5) showed that attention function improved significantly but executive and planning functions didn't improve in the patients with high scores in the Epworth's scale following treatment with CPAP, suggesting that restricted cognitive alteration might be associated with other mechanisms as well and that sleep fragmentations might also be involved in them. CPAP treatment has effects especially on improves in attention and memory functions short-time memory. It was observed in the present study as well that symptom of daytime sleepiness reduced significantly when the pre- and post-treatment periods were compared.

Opinions on duration of affectivity of CPAP treatment are variable. Some studies suggested that there was no relationship between duration of CPAP treatment and cognitive improvement $(23,41)$ whereas others suggested that duration of treatment might range from 1 week to 12 months (23). Neuropsychological effects of one-week CPAP treatment in patients with OSA: a placebo-controlled study (41). Long-term effects of CPAP on daytime functioning in patients with sleep apnea syndrome (41).

The patients using CPAP very well, intermediately and infrequently were taken as 3 separate groups and it was observed that those using the treatment very well and intermediately had significant improvement while the treatment was ineffective in those using it infrequently (in less hours). In conclusion, the best results were obtained in the patients using the treatment at optimal level for 3 months (40).

In consistence with other studies, it was seen that significant improvement occurred in attention, memory functions and decrease in daytime sleepiness following 3 months of CPAP treatment.

\section{Conclusion}

In conclusion although significant differences exist, cognitive impairment is frequently observed in the studies on OSAS and clinical meaning of the detected changes is still uncertain. This originates from difficulties in establishing cognitive skills and limitations of the cognitive tests and study models. Research suffers from the differences in severity of disease, co-morbid medical conditions, and probably age-related changes affecting cognitive function among the study groups. No subjects with co-morbid conditions were included in the present study. Further studies are needed with higher number of subjects, in which we can evaluate the treatment for a longer time.

\section{Ethic}

Ethics Committee Approval: The study was approved by Celal Bayar University Faculty of Medicine Local Ethics Committee (date/approval no: 16.04.2014/20478486).

Inform Consent: It was taken.

Peer-review: Externally peer-reviewed.

\section{Authorship Contributions}

Surgical and Medical Practices: A.K.A., Ü.S.S., Concept: A.K.A., Ü.S.S., H.Y., Design: A.K.A., Ü.S.S., H.Y., Data Collection or Processing: Ü.S.S., B.O., T.K., Analysis or Interpretation: A.K.A., G.D.H., D.S., H.Y., Literature Search: A.K.A., H.Y., Writing: A.K.A., H.Y.

Conflict of Interest: No conflict of interest was declared by the authors.

Financial Disclosure: This study was supported by Scientific Researches Project of Celal Bayar University (no: 2014-138).

\section{References}

1. Bixler EO, Vgontzas AN, Lin HM ,Ten Have T, Rein J, Vela-Bueno A, Kales A. Prevalence of sleep disordered breathing in women: effects of gender. Am J Respir Crit Care Med 2001;163:608-13.

2. Verstraeten E. Neurocognitive effects of obstructive sleep apnea syndrome. Curr Neurol Neurosci Rep 2007;7:161-6.

3. Durmer JS, Dinges DF. Neurocognitive consequences of sleep deprivation. Semin Neurol 2005;25:117- 29.

4. Young T, Palta M, Dempsey J, Skatrud J, Weber S, Badr S. The occurrence of sleep-disordered breathing among middle-aged adults. N Engl J Med 1993;328:1230-5.

5. Ferini-Strambi L, Baietto C, Di Gioia MR, Castaldi P, Castronovo C, Zucconi M, Cappa SF. Cognitive dysfunction in patients with obstructive sleep apnea (OSA): partial reversibility after continuous positive airway pressure (CPAP). Brain Res Bull 2003;61:87-92.

6. Salorio CF, White DA, Piccirillo J, Duntley SP, Uhles ML. Learning, memory, and executive control in individuals with obstructive sleep apnea syndrome. J Clin Exp Neuropsychol 2002;24:93-100.

7. Naismith S, Winter V, Gotsopoulos H, Hickie I, Cistulli P. Neurobehavioral functioning in obstructive sleep apnea: differential effects of sleep quality, hypoxemia and subjective sleepiness. J Clin Exp Neuropsychol 2004;26:43-54. 
8. Lis S, Krieger S, Hennig D, Röder C, Kirsch P, Seeger W. Executive functions and cognitive subprocesses in patients with obstructive sleep apnoea. J Sleep Res 2008;17:271-80.

9. Beebe DW, Groesz L, Wells C, Nichols A, McGee K. The neuropsychological effects of obstructive sleep apnea: a metaanalysis of norm-referenced and case controlled data. Sleep 2003;26:298-307.

10. Boland LL, Shahar E, Iber C, Knopman DS, Kuo TF, Nieto F); Sleep Heart Health Study (SHHS) Investigators. Measures of cognitive function in persons with varying degrees of sleep- disordered breathing: (The Sleep Heart Health Study). J Sleep Res 2002;11:265-72.

11. Decary A, Rouleau I, Montplaisir. Cognitive deficits associated with sleep apnea syndrome: a proposed neuropsychological test battery. Sleep 2000;23:369-81.

12. Redline S, Strauss ME, Adams N, Winters M, Roebuck T, Spry K, Rosenberg C, Adams K. Neuropsychological function in mild sleepdisordered breathing. Sleep 1997;20:160-7.

13. Roth T, Costa e Silva JA, Chase MH. Sleep and cognitive (memory) function: research and clinical perspectives. Sleep Med 2001;2:379-87.

14. Sateia MJ. Neuropsychological impairment and quality of life in obstructive sleep apnea. Clin Chest Med 2003;24:249-59.

15. Brown AW, Brierley JB. The earliest alterations in rat neurons and astrocytes after anoxia-ischemia. Acta Neuropathol 1973;23:9-22.

16. Lavie L. Obstructive sleep apnea syndrome--an oxidative stres disorder. Sleep Med Rev 2003;7:35-51.

17. Aloia MS, Arnedt JT, Davis JD, Riggs RL, Byrd D. Neuropsychological sequelae of obstructive sleep apnea-hypopnea syndrome: a critical review. J Int Neuropsychol Soc 2004;10:772-85.

18. Sateia MJ. Neuropsychological impairment and quality of life in obstructive sleep apnea. Clin Chest Med 2003;24:249-59.

19. Manukhina EB, Downey HF, Mallet RT. Role of nitric oxide in cardiovascular adaptation to intermittent hypoxia. Exp Biol Med (Maywood) 2006;231:343-65.

20. Kotterba S, Rasche K, Widdig W, Duscha C, Blombach S, SchultzeWerninghaus G, Malin JP. Neuropsychological investigations and event-related potentials in obstructive sleep apnea syndrome before and during CPAP-therapy. J Neurol Sci 1998;159:45-50.

21. Alchanatıs M, Zias N, Deligiorgis N, Amfilochiou A, Dionellis G, Orphanidou D. Sleep apne-related cognitive deficits and intelligence: an implication of cognitive reserve theory. J Sleep Res 2005;14:69-75.

22. Delgado Rodrigues RN, Alvim de Abreu E Silva Rodrigues AA, Pratesi $\mathrm{R}$, Krieger J. Outcome of restless legs severity after continuous positive air pressure (CPAP) treatment in patients affected by the association of RLS and obstructive sleep apneas. Sleep Med 2006:7:235-9.

23. Bardwell WA, Ancoli-Israel S, Berry CC, Dimsdale JE. Neuropsychological effects of one-week continuous positive airway pressure treatment in patients with obstructive sleep apnea: a placebo-controlled study. Psychosom Med 2001;63:579-84.

24. Martins $\mathrm{CH}$, Castro Júnior Nd, Costa Filho OA, Souza Neto OM. Braz Obstructive sleep apnea and P300 evoked auditory potential. Braz J Otorhinolaryngol 2011;77:700-5.
25. Rumbach L, Krieger I, Kurtz D. Auditory Event Related Potentials in Obstructive Sleep Apnea Effects of Treatment with Nasal Continuous Positive Airway Pressure. Electroencephalogr Clin Neurophysiol 1991;80:454-7.

26. Cohen-Zion M, Stepnowsky C, Marler M, Shochat T, Kripke DF, Ancoli-Israel $\mathrm{S}$. Changes in cognitive function associated with sleep disordered breathing in older people. I Am Geriatr Soc 2001;49:1622-7.

27. Ohayon MM, Vecchierini MF. Daytime sleepiness and cognitive impairment in the elderly population. Arch Intern Med 2002; 162:201-8.

28. Bedard M, Montplaisir J, Richer F, Rouleau I, Malo J. Obstructive sleep apnea syndrome: pathogenesis of neuropsychological deficits. J Clin Exp Neuropsychol 1991;13:950-64.

29. Naegele B, Thouvard V, Pépin JL, Lévy P, Bonnet C, Perret JE, Pellat J, Feuerstein C. Deficits of cognitive executive functions in patients with sleep apnea syndrome. Sleep 1995; 18:43-52.

30. Kloepfer C, Riemann D, Nofzinger EA, Feige B, Unterrainer J, O'Hara, Sorichter S, Nissen C. Memory before and after sleep in patients with moderate obstructive sleep apnea. J Clin Sleep Med 2009;5:540-8.

31. Twigg GL, Papaioannou I, Jackson M, Ghiassi R, Shaikh Z, Jaye J, Graham KS, Simonds AK, Morrell MJ. Obstructive sleep apnea syndrome is associated with deficits in verbal but not visual memory. Am J Respir and Crit Care Med 2010;182:98-103.

32. Mazza S, Pépin JL, Naëgelé B, Plante J, Deschaux C, Lévy P. Most obstructive sleep apnea patients exhibit vigilance and attention deficits on an extended battery of tests. Eur Respir J 2005;25:75-80.

33. Archbold KH, Borghesani PR, Mahurin RK, Kapur VK, Landis CA. Neural activation patterns during working memory tasks and OSA disease severity: preliminary findings. J Clin Sleep Med 2009;5:21-7.

34. Raggi A, Ferri R. Cognitive evoked potentials in obstructive sleep apnea syndrome: a review of the literature. Rev Neurosci 2012;23:311-23.

35. Morris AM, So Y, Lee KA, Lash AA, Becker CE. The P300 event related potential. The effects of sleep deprivation. J Occup Med 1992;34:1143-52.

36. Lee HJ, Kim L, Suh KY. Cognitive deterioration and changes of P300 during total sleep deprivation. Psychiatry Clin Neurosci 2003;57:490-6.

37. Fjell AM, Walhovd KB. Effects of auditory stimulus intensity and hearing threshold on the relationship among P300, age and cognitive function. Clin Neurophysiol 2003;114:799-807.

38. Sangal RB, Sangal JM. Abnormal visual P300 latency in obstructive sleep apnea does not change acutely upon treatment with CPAP. Sleep 1997;20:702-4.

39. Inoue Y, Nanba K, Kojima K, Mitani H, Arai AH. P 300 abnormalities in patients with severe sleep apnea syndrome. Psychiatry Clin Neurosci 2001;55:247-8.

40. Zimmerman ME, Arnedt JT, Stanchina M, Millman RP, Aloia MS. Normalization of memory performance and positive airway pressure adherence in memory impaired patients with obstructive sleep apnea. Chest 2006;130:1772-8.

41. Muñoz A, Mayoralas LR, Barbé F, Pericás J, Agusti AG. Long-term effects of CPAP on day time functioning in patients with sleep apnoea syndrome. Eur Respir J. 2000;15:676-81. 